
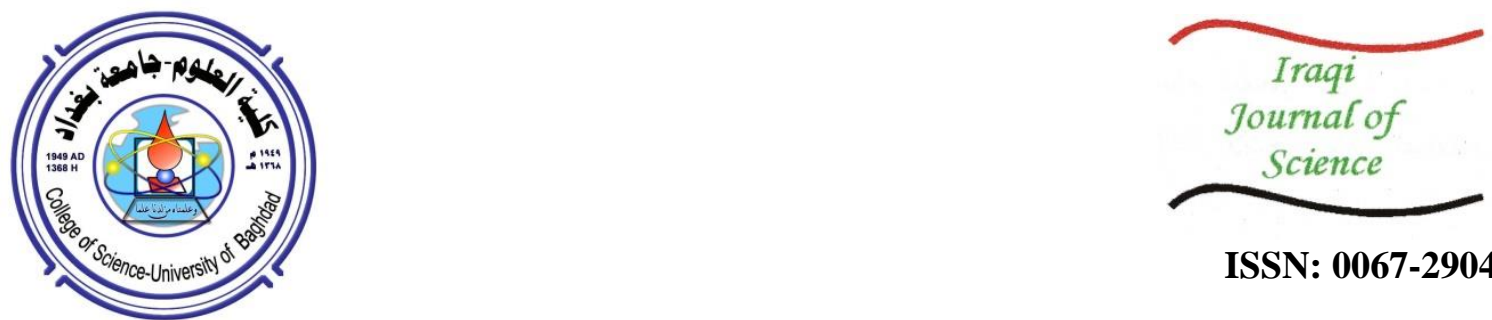

ISSN: 0067-2904

\title{
Sources of Heavy Minerals of the Neogene Clastics at Bekhme, Northern Iraq
}

\author{
Saif Al-Ddin A. Al-Rawi*, Suhad Khalaf A. Razzak \\ Department of Geology, College of Science, University of Baghdad, Baghdad, Iraq
}

Received: 22/10/2019

Accepted: $15 / 3 / 2020$

\begin{abstract}
Ten samples were collected from Injana and Mukdadiya Formations, representing 5 samples of fine grain sandstone $(\mathrm{F})$ and 5 samples of very fine grain sandstone (VF). The heavy metals study showed that the opaque mineral recorded the highest percentage in comparison with other heavy metals. While, transparent minerals, including unstable minerals (Amphibole including Hornblend and Glaucophane) and (pyroxene including Orthopyroxene and Clinopyroxene), Metastable minerals including (Epidote, staurolite, Garnet, Kyanite) indicated metamorphic source, Ultrastable minerals (Zircon, Rutile, Tourmaline), Mica group (chlorite, biotite and muscovite). These accumulations indicate that the heavy minerals are derived from mafic igneous and metamorphic rocks mostly, as well as acidic igneous and reworked sediments. Ternary diagram of heavy metals stability showed that they are moderately stable due to the effect of the opaque mineral that have highest attention. Both sandstones for the Injana and Mukdadiya formations are derived from active continental margins. This source rocks may be represented by Taurus and Zagros Mountains.
\end{abstract}

Keywords: Heavy minerals, Provenance, Injana Formation, Mukdadiya Formation.
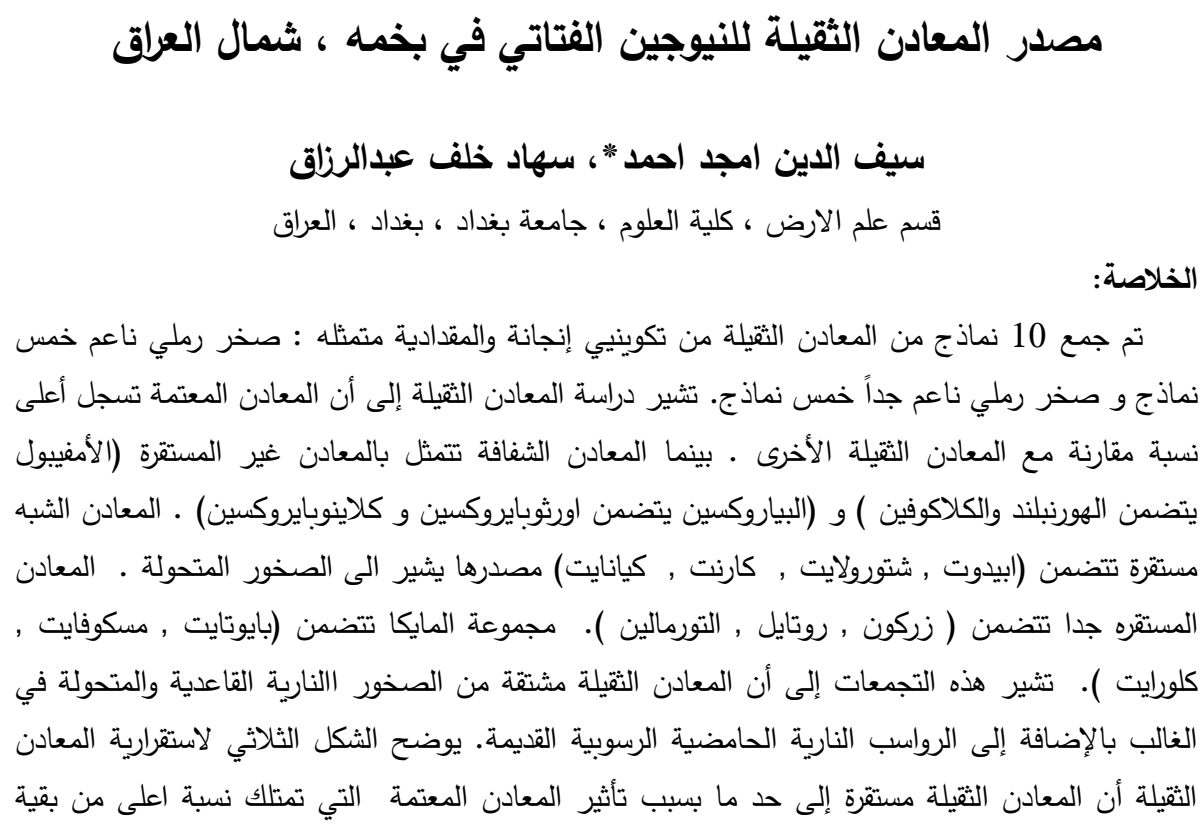


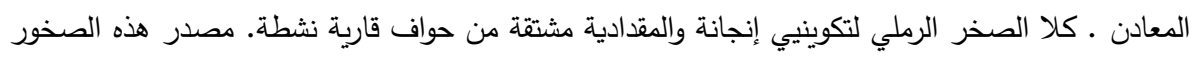

\section{Introduction}

$$
\text { قد يكون جبال طوروس وزاغروس. }
$$

The clastic Neogene succession in the Bekhme area consists of Injana and Mukdadiya Formations (previously called Upper Fars and Lower Bakhtiari Formations, respectively). They are of the Upper Miocene-Pliocene age and are widely exposed throughout Iraq. They were defined for the first time by Busk and Mayo in 1918 [1]. The Injana Formation characterizes the lower fine-grained molasses sediments deposited at the beginning in marine and progressively in fluvial and lacustrine environments [2]. The Mukdadyia Formation consists of a fining-upward succession of gravelly sandstone, sandstone and mudstone. It is deposited in a fluvial environment in a quickly subsiding foredeep basin [3]. The terms of the Upper Fars and Lower Bakhtiari Formations, respectively, were replaced by Injana and Mukdadiya Formations [4]. The lower contact of the Injana Formation with the Fatha Formation is gradational. The upper contact with the Mukdadiya Formation is gradational, marked by the appearance of gravely sandstone [5]. Injana and Mukdadiya are widely studied because of their extension and good exposure. Such studied are [6], [7], [8] for Injana Formation and [8], [9], [10] for Mukdadiya Formation. The outcrops of Injana and Mukdadiya Formation are located in Bekhma area, northern of Iraq. The coordinates for the study area are Longitude $44^{\circ} 13^{\prime} 32^{\prime \prime} \mathrm{E}$, Latitude $36^{\circ} 39^{\prime} 2^{\prime \prime} \mathrm{N}$ for Injana Formation and Longitude $44^{\circ} 13^{\prime} 25^{\prime \prime} \mathrm{E}$, Latitude $36^{\circ} 38^{\prime} 58^{\prime \prime} \mathrm{N}$ for Mukdadiya Formation (Figure-1). The aim of this study is interpret the provenance and tectonic setting of the provenance area using heavy metals data.

\section{Geological Setting}

The studied region is located at the High Folded Zone (Outer Platform, Western Zagros Fold-Thrust Belt [11]) as shown in Figure-1. Injana and Mukdadiya Formations are parts of the Arabian Plate Tectonostratigraphic Megasequnce AP11 [12]. This megasequence is defined as the package of sediments representing the latest Eocene-Recent. It is associated with the collision of Neo-Tethyan terrains along the $\mathrm{N}$ and $\mathrm{E}$ sides of the Arabian Plate, as well as the opening of the Gulf of Aden and the Red Sea on the S and W sides of the plate. The N and NE drifts of Arabia and the closure of the Neo-Tethyan terranes laterally border the NE margin of the Arabian Plate.

In the High Folded Zones of $\mathrm{N}$ and NE Iraq, the megasequence is controlled by Mio-Pliocene molasse which is up to $3000 \mathrm{~m}$ thick in the foredeep basin sited to the SW of the Zagros Suture [5]. The Upper Miocene-Pliocene cycle is characterized by the progressive change from the marine sedimentation into the lacustrine and fluviatile. This change was accompanied by the gradational coarsening of the clastics laid down during the cycle. The main source area of the clastics was the increasing mountain in the northeast of Iraq [2]. In Late Miocene-Pliocene time, a main thrusting occurred during the collision of the Neo-Tethyan terranes and the Sanandaj-Sirjan Zone with the Arabian Plate. This event resulted in the uplift of the High Folded, Northern Thrust Zones and the NE part of Balambo-Tanjero and Mesopotamian Zones. Through the Late Miocene and particularly in the Pliocene, the High Folded Zone was uplifted with increasing intensity; the products of erosion were deposited in the proximate molasses basin. 


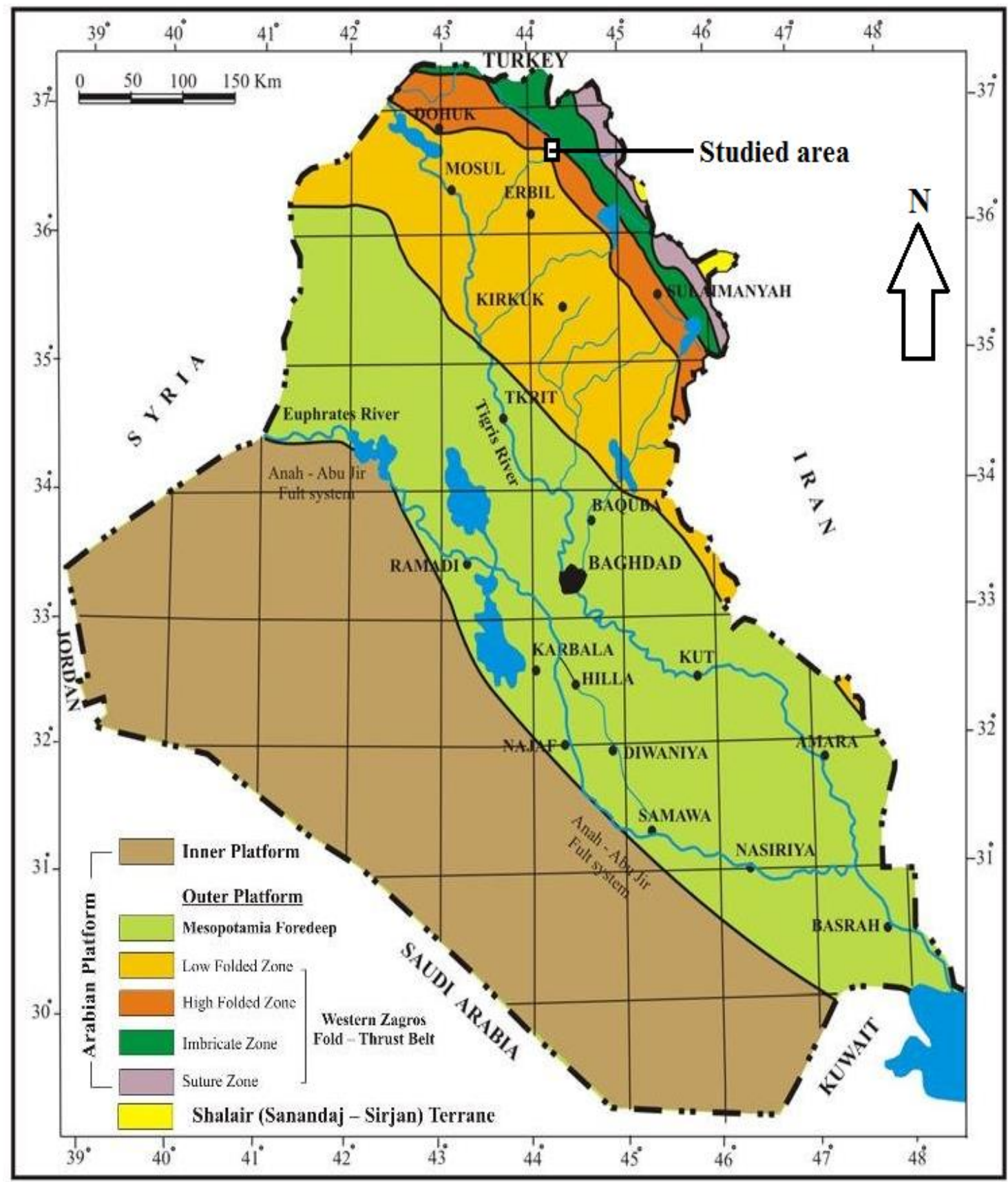

Figure 1- Tectonic and location map of the study area [11].

\section{Materials and Methods}

Ten samples of heavy minerals were chosen in order to be identified by a polarized microscope. The process of minerals separation was conducted following previous procedures [13-14]. Sand fractions were separated using sieves with size fractions of $2 \mathrm{~mm}, 1 \mathrm{~mm}, 0.5 \mathrm{~mm}, 0.25 \mathrm{~mm}, 0.125 \mathrm{~mm}$, and $0.063 \mathrm{~mm}$. The $3 \varnothing(0.125 \mathrm{~mm})$ fine grain $(F)$ and $4 \varnothing(0.063 \mathrm{~mm})$ very fine grain $(\mathrm{VF})$ were obtained by dry sieving. Five grams of grains of both sizes were used for minerals separation, using a Bromoform of a density of 2.89 , followed by mounting on glass slide using 300-500 grains per slide, following the method of Fleet [14].

\section{Results}

Two sets of heavy metals were identified and described in the current studied samples (Table-1), as described below.

\section{A- Opaque Minerals}

Opaque minerals of iron oxides are found in two types, dark brown and black opaque. The grains of these minerals are generally sub angular to angular and some grains are sub rounded to rounded. The 
percentage of opaque minerals in Injana sandstone ranged between 37- 42.9\% (average 39.8\%). The percentage in Mukdadiya sandstone ranged between 36.7- 40.8\% (average 38.5\%) (Figure- 2-A).

Chromian spinel was recorded in some samples of Injana and Mukdadiya sandstone. Grains of chromian spinel occur as angular to subrounded, equant in shape, with dark reddish to red colors. Chromian spinal is isotropic. The percentage of chromian spinel in Injana sandstone ranged between $0-1.8 \%$ (average 0.6). In Mukdadiya sandstone the percentage ranged between $0-1.5 \%$ (average 0.9 \%) (Figure- 2-B).

B- Transparent minerals. According to the division of Folk [15], depending on the stability of heavy minerals, heavy minerals can be divided into the following groups:

1- Unstable minerals which include the following:

\section{A. Glaucophane}

Glaucophane can be found in some samples of Injana and Mukdadiya sandstone. The grains are pleochroic, deep blue to violet, subhedral and irregular in shape, and mostly fresh. There percentage in Injana sandstone ranged between 0- 0.9\% (average 0.2\%), whereas in Mukdadiya sandstone the percentage ranged between $0-0.9 \%$ (average $0.4 \%$ ) (Figure- 2-B).

Table 1- Percentage, range and average of heavy minerals levels in Injana and Mukdadiya sandstone at Bekhma sections

\begin{tabular}{|c|c|c|c|c|c|c|c|c|c|c|c|c|c|c|c|c|c|c|c|}
\hline & 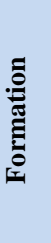 & 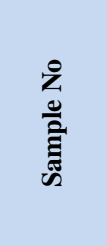 & 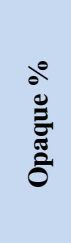 & 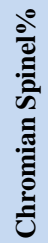 & 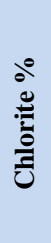 & 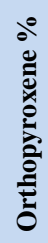 & 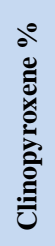 & 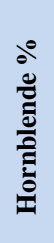 & 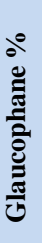 & 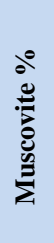 & 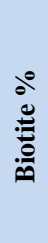 & 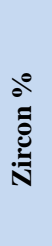 & 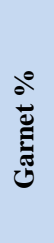 & 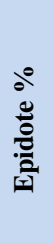 & 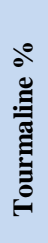 & 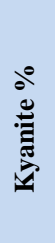 & 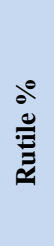 & 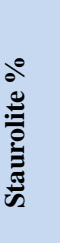 & 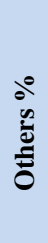 \\
\hline \multirow{14}{*}{ פू. } & \multirow{14}{*}{ 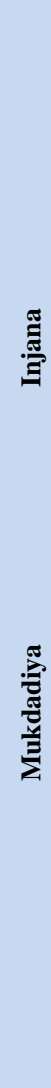 } & $1 F$ & 41.5 & 0 & 7.8 & 4.3 & 4.6 & 7.3 & 0 & 3.6 & 4.2 & 3.5 & 3.5 & 8.7 & 3.6 & 2.9 & 1.3 & 2.7 & 0.5 \\
\hline & & $1 \mathrm{VF}$ & 38.5 & $\begin{array}{l}1 . \\
2\end{array}$ & 6.8 & 4.8 & 4.5 & 7.8 & $\begin{array}{l}0 . \\
9\end{array}$ & 4.2 & 5.2 & 3.8 & 4.3 & 7.2 & 3.4 & 2.9 & 1.3 & 2.6 & 0.6 \\
\hline & & $2 F$ & 38.7 & $\begin{array}{l}0 . \\
6\end{array}$ & 8.3 & 4 & 5.7 & 7.6 & 0 & 3.3 & 4 & 4.5 & 4.6 & 7.2 & 3.4 & 2.8 & 1.4 & 2.7 & 1.2 \\
\hline & & $2 \mathrm{VF}$ & 42.9 & 0 & 7.2 & 4.8 & 3 & 6.6 & 0 & 4 & 5.4 & 3.3 & 5.2 & 6.8 & 2.2 & 2.5 & 2.5 & 2.5 & 1.1 \\
\hline & & $3 F$ & 37 & $\begin{array}{l}1 . \\
8\end{array}$ & 6.7 & 5.6 & 5.5 & 8.4 & 0 & 3.2 & 4.6 & 3.2 & 4.6 & 8.8 & 3.4 & 2.9 & 1.8 & 1.1 & 1.4 \\
\hline & & 3VF & 40.1 & 0 & 7.5 & 2.5 & 3.1 & 7.5 & 0 & 3.6 & 6.4 & 3.3 & 4.4 & 8.5 & 4.9 & 1.8 & 2.5 & 2.8 & 1.1 \\
\hline & & Range & $\begin{array}{c}37- \\
42.9\end{array}$ & $\begin{array}{l}0- \\
1 . \\
8\end{array}$ & $\begin{array}{c}6.7 \\
- \\
8.3\end{array}$ & $\begin{array}{c}2.5 \\
- \\
5.6\end{array}$ & $\begin{array}{c}3- \\
5.7\end{array}$ & $\begin{array}{c}6.6 \\
- \\
8.4\end{array}$ & $\begin{array}{l}0- \\
0 . \\
9\end{array}$ & $\begin{array}{c}3.2 \\
- \\
4.2\end{array}$ & $\begin{array}{l}4- \\
6.4\end{array}$ & $\begin{array}{c}3.2 \\
- \\
4.5\end{array}$ & $\begin{array}{c}3.5 \\
- \\
5.2\end{array}$ & $\begin{array}{c}6.8 \\
- \\
8.8\end{array}$ & $\begin{array}{c}2.2 \\
- \\
4.9\end{array}$ & $\begin{array}{c}1.8 \\
- \\
2.9\end{array}$ & $\begin{array}{c}1.3 \\
- \\
2.5\end{array}$ & $\begin{array}{c}1.1 \\
- \\
2.8\end{array}$ & $\begin{array}{c}0.5 \\
- \\
1.4\end{array}$ \\
\hline & & $\begin{array}{c}\text { Averag } \\
\text { e }\end{array}$ & 39.8 & $\begin{array}{l}0 . \\
6\end{array}$ & 7.4 & 4.3 & 4.4 & 7.5 & $\begin{array}{l}0 . \\
2\end{array}$ & 3.7 & 5 & 3.6 & 4.4 & 7.9 & 3.5 & 2.6 & 1.8 & 2.4 & 1 \\
\hline & & $4 F$ & 38.1 & $\begin{array}{l}1 . \\
2\end{array}$ & 8.1 & 3.7 & 4.8 & 6 & $\begin{array}{l}0 . \\
9\end{array}$ & 3.6 & 4.3 & 4.7 & 3.6 & 8.8 & 3.3 & 2.7 & 1.8 & 2.1 & 1.3 \\
\hline & & $4 \mathrm{VF}$ & 38.2 & $\begin{array}{l}1 . \\
5\end{array}$ & 8.3 & 3.5 & 4.8 & 6.7 & 0 & 4.9 & 5.4 & 3.6 & 5.5 & 6.9 & 2.5 & 2.4 & 2.5 & 2.2 & 1.1 \\
\hline & & $5 F$ & 40.8 & 0 & 8.5 & 3.6 & 5.4 & 7.6 & 0 & 3.3 & 4.4 & 3.3 & 4.4 & 7.7 & 3.7 & 2.2 & 1.6 & 2.3 & 1.2 \\
\hline & & $5 \mathrm{VF}$ & 36.7 & $\begin{array}{l}0 . \\
9\end{array}$ & 8.4 & 4.5 & 4.7 & 5.1 & $\begin{array}{l}0 . \\
6\end{array}$ & 4.4 & 5.3 & 4.4 & 4.8 & 8.1 & 4.7 & 2.7 & 1.7 & 1.8 & 1.2 \\
\hline & & Range & $\begin{array}{c}36.7 \\
- \\
40.8\end{array}$ & $\begin{array}{l}0- \\
1 . \\
5\end{array}$ & $\begin{array}{c}8.1 \\
- \\
8.5\end{array}$ & $\begin{array}{c}3.5 \\
- \\
4.5\end{array}$ & $\begin{array}{c}4.7 \\
- \\
5.4\end{array}$ & $\begin{array}{c}5.1 \\
- \\
7.6\end{array}$ & $\begin{array}{l}0- \\
0 . \\
9\end{array}$ & $\begin{array}{c}3.3 \\
- \\
4.9\end{array}$ & $\begin{array}{c}4.3 \\
- \\
5.4\end{array}$ & $\begin{array}{c}3.3 \\
- \\
4.7\end{array}$ & $\begin{array}{c}3.6 \\
- \\
5.5\end{array}$ & $\begin{array}{c}6.9 \\
- \\
8.8\end{array}$ & $\begin{array}{c}2.5 \\
- \\
4.7\end{array}$ & $\begin{array}{c}2.2 \\
- \\
2.7\end{array}$ & $\begin{array}{c}1.6 \\
- \\
2.5\end{array}$ & $\begin{array}{c}1.8 \\
- \\
2.3\end{array}$ & $\begin{array}{c}1.1 \\
- \\
1.3\end{array}$ \\
\hline & & $\begin{array}{c}\text { Averag } \\
\text { e }\end{array}$ & 38.5 & $\begin{array}{l}0 . \\
9\end{array}$ & 8.3 & 3.8 & 4.9 & 6.4 & $\begin{array}{l}0 . \\
4\end{array}$ & 4.1 & 4.9 & 4 & 4.6 & 7.9 & 3.6 & 2.5 & 1.9 & 2.1 & 1.2 \\
\hline
\end{tabular}




\section{B. Hornblende}

Hornblende is found in all samples of Injana and Mukdadiya sandstone. Its grains are green in color, tabular, prismatic, cleaved, and mostly fresh, with some showing a degree of alteration from euhedral to subhedral. The percentage of Hornblende in Injana sandstone ranges between 6.6-8.4\% (average 7.5\%). In Mukdadiya sandstone the percentage ranges between 5.1-7.6\% (average 6.4\%) (Figure- 2-C).

\section{Orthopyroxene}

Orthopyroxene is recorded in all the examined samples of Injana and Mukdadiya sandstone. Orthopyroxene grains usually showed colorless to light green color with a prismatic and pattern. There percentage in Injana sandstone ranged between 2.5-5.6\% (average 4.3\%). In Mukdadiya sandstone the percentage ranged between 3.5-4.5\% (average 3.8 \%) (Figure- 2-D).

\section{Clinopyroxene}

Clinopyroxene is recorded in all the examined samples of Injana and Mukdadiya sandstone. Clinopyroxene grains were observed as high relief and prismatic, subhedral, and irregular in shape. They were colorless or of pale green and green color. There percentage in Injana sandstone ranged between 3-5.7\% (average 4.4\%). In Mukdadiya sandstone the percentage ranged between 4.7- 5.4\% (average $4.9 \%$ ) (Figure- 2-E).

\section{2- Metastable minerals}

\section{A. Epidotes}

Epidotes are recorded in all samples of Injana and Mukdadiya sandstone. is the grains are usually present in subangular to subrounded shape, high relief, and green to olive green color. The percentage of epidotes in Injana sandstone is ranging between $6.8-8.8 \%$ (average $7.9 \%$ ). The percentage of epidotes in Mukdadiya sandstone is ranging between 6.9-8.8\% (average 7.9\%) (Figure- 2-F).

\section{B. Staurolite}

Staurolite is found in all samples of Injana and Mukdadiya sandstone. Saurolite grains show high relief, yellowish to golden color, with pleochroism, subhedral to sub rounded shape. The percentage of Staurolite in Injana sandstone ranges between 1.1-2.8\% (average 2.4\%). In Mukdadiya sandstone its percentage ranges between $1.8-2.3 \%$ (average $2.1 \%$ ) (Figure- $2-\mathrm{G}$ ).

\section{Garnet}

Garnet is observed in all the studied samples of Injana and Mukdadiya sandstone. Garnet occurred in angular to subrounded high relief, mostly fresh grains which were equant to subequant in shape, with colorless and light brown color. There percentage in Injana sandstone ranges between 3.5-5.2\% (average 4.4\%). In Mukdadiya sandstone the percentage of garnet is ranging between 3.6- 5.5\% (average $4.6 \%$ ) (Figure- 2-H).

\section{Kyanite}

Kyanite is recorded in all examined samples of Injana and Mukdadiya sandstone. Kyanite grains are colorless, high relief, subhedral with elongated or prismatic shape. The percentage of Kyanite in Injana sandstone ranges between $1.8-2.9 \%$ (average $2.6 \%$ ). In Mukdadiya sandstone its percentage ranges between $2.2-2.7 \%$ (average $2.5 \%$ ) (Figure- 2-I).

\section{3- Ultra stable minerals}

\section{A. Zircon}

The presence of zircon grains is recorded in all of the examined samples of Injana and Mukdadiya sandstone. Zircon occurred in a prismatic form and an euhedral to subhedral shape, while subrounded and rounded grains were also recorded. Zircon grain is usually clear and colorless, with a very high relief. There percentage in Injana sandstone ranged between 3.2-4.5\% (average 3.6\%). In Mukdadiya sandstone its percentage ranged between 3.3- 4.7\% (average 4\%) (Figure- 2-J).

\section{B. Tourmaline}

Tourmaline is recorded in all examined samples of Injana and Mukdadiya sandstone. Tourmaline grains have the honey color with pleochroism and high relief. They are sub rounded to rounded in form and mostly fresh, Subhedral grains are also observed in some samples. The percentage of tourmaline in Injana sandstone ranges between 2.2-4.9\% (average 3.5\%). In Mukdadiya sandstone its percentage ranges between 2.5-4.7\% (average 3.6\%) (Figure- 2-K).

\section{Rutile}

Rutile is found in all samples of Injana and Mukdadiya sandstone, rutile occurred as elongated subhedral and irregular grains, with deep red color and very high relief. The percentage of Rutile in 
Injana sandstone ranges between 1.3-2.5\% (average 1.8\%). In Mukdadiya sandstone its percentage ranges between 1.6-2.5\% (average 1.9\%) (Figure- 2-L).

\section{4- Flaky minerals or Mica}

\section{A. Chlorite}

Chlorite grains are observed in most of the examined samples of Injana and Mukdadiya sandstone. Chlorite grains occurred as flaky, irregular in shape with subrounded to rounded edges, and fresh chlorite is common and shows a deep bluish green to green color. Chlorite grains show inclusions of opaque minerals (iron oxides) .The percentage of chlorite in Injana sandstone ranged between 6.7$8.3 \%$ (average $7.4 \%$ ). In Mukdadiya sandstone the percentage of chlorite ranged between $8.1-8.5 \%$ (average $8.3 \%$ ) (Figure- 2-M).

\section{B. Biotite}

Biotite is recorded in all the examined samples of Injana and Mukdadiya sandstone. Biotite occurred in a flaky form and angular to irregular shape, with reddish and brown pleochroic colors. The percentage of Biotite in Injana Formation ranged between 4-6.4\% (average $5 \%$ ). In Mukdadiya sandstone the percentage ranged between $4.3-5.4 \%$ (average $4.9 \%$ ) (Figure- 2-N).

\section{Muscovite}

Muscovite is recorded in all the examined samples of Injana and Mukdadiya sandstone. Muscovite occurred in a flaky form and irregular to subangular shape, being transparent and colorless with low relief. The percentage of muscovite in Injana sandstone ranged between 3.2-4.2\% (average 3.7\%). In Mukdadiya sandstone the percentage ranged between 3.3- 4.9\% (average 4.1\%) (Figure- 2-O).

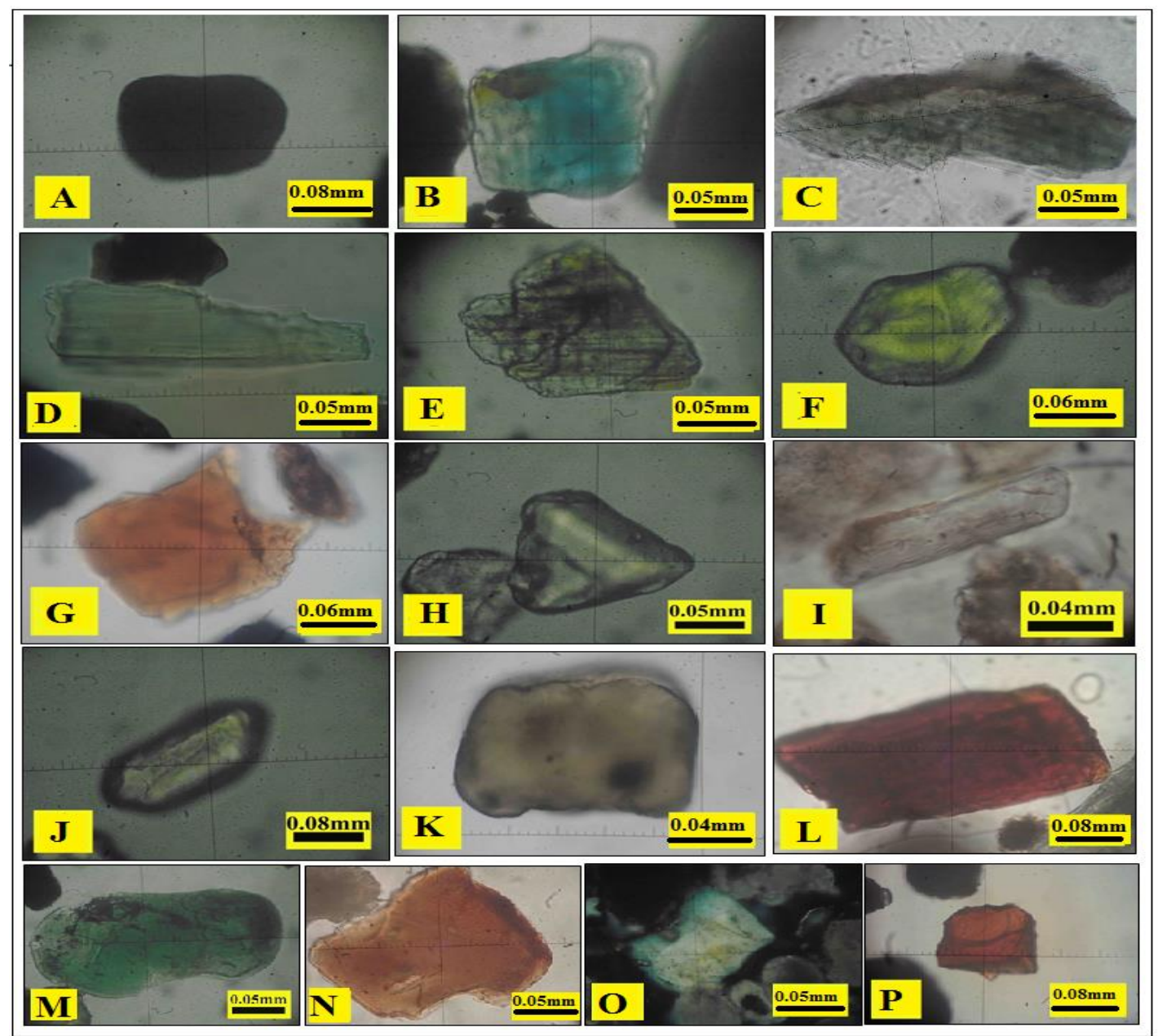

Figure 2- Photomicrograph of heavy minerals of Injana and Mukdadiya sandstones: A- Opaque mineral, B- Amphibole (Glaucophane), C- Amphibole (hornblende), D- Orthopyroxene, and EClinopyroxene, F- Epidote G- Staurolite, H- Garnet, and I- Kyanite, J- Zircon, K- tourmaline, LRutile, M- Chlorite, and N- Biotite, O- Muscovite, P- Chromian Spinel. 


\section{Stability of Heavy Minerals}

There are several classifications that divide heavy minerals into groups depending on their relative stability. A previous work [15] divided the heavy minerals into four groups. Another study [16] suggested a ternary diagram for the determination of the stability of heavy minerals content, in which unstable, moderately stable and ultra-stable groups are considered, where heavy minerals were recalculated to $100 \%$ (Table 3-5). Application of the stability factor on the studied sandstone of Injana and Mukdadiya Formations showed that all samples are moderately stable (Figure -3).

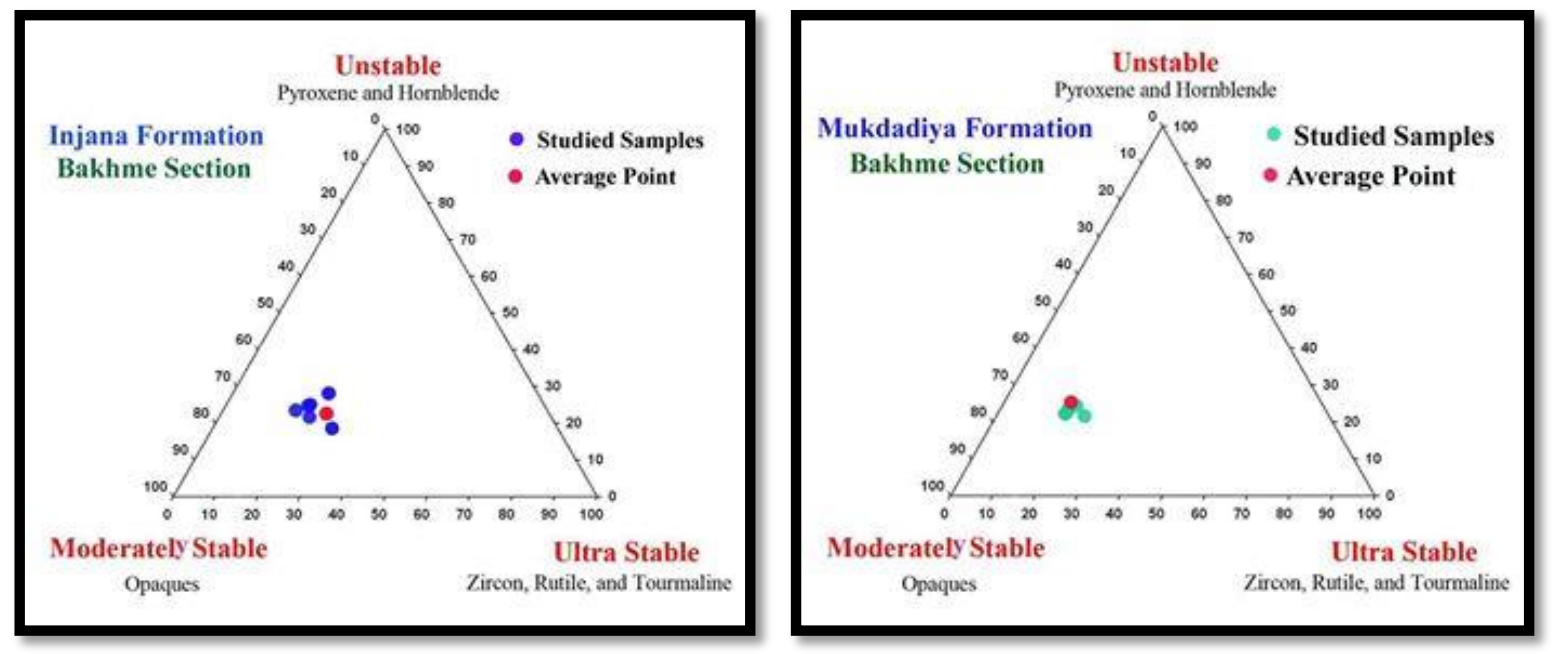

Figure 3- Ternary diagram of heavy mineral stability of Injana and Mukdadiya sandstone, after [16].

\section{Heavy mineral assemblage and continental margin activity}

The relation between tectonic and sediment composition has been long recognized [17]. Nechoev and Isophroding [18] suggested a plate tectonic analysis of heavy mineral data by comparing the assemblage with the possible sources of clastic sediment resulting from different stages of the plate tectonic cycle. They constructed a triangular diagram (MF, GM, and MT) which makes a linkage between the plate tectonic setting and the heavy mineral assemblage, where:

MF: common constituents of mafic magmatic rocks.

MT: common constituents of basic metamorphic rocks.

GM: Accessory minerals of granites and sialic metamorphic rocks.

The data of MF, GM and MT rocks were recalculated to $100 \%$. Plotting of the studied samples of Injana and Mukdadiya Formation on the ternary diagram showed that all the samples fall within the field of active continental margins (Figure -4), which are characterized by a relatively high percentage of minerals derived from basic rocks. Both sandstones are derived from active continental margins. This source rocks may be represented by Taurus and Zagros Mountains.
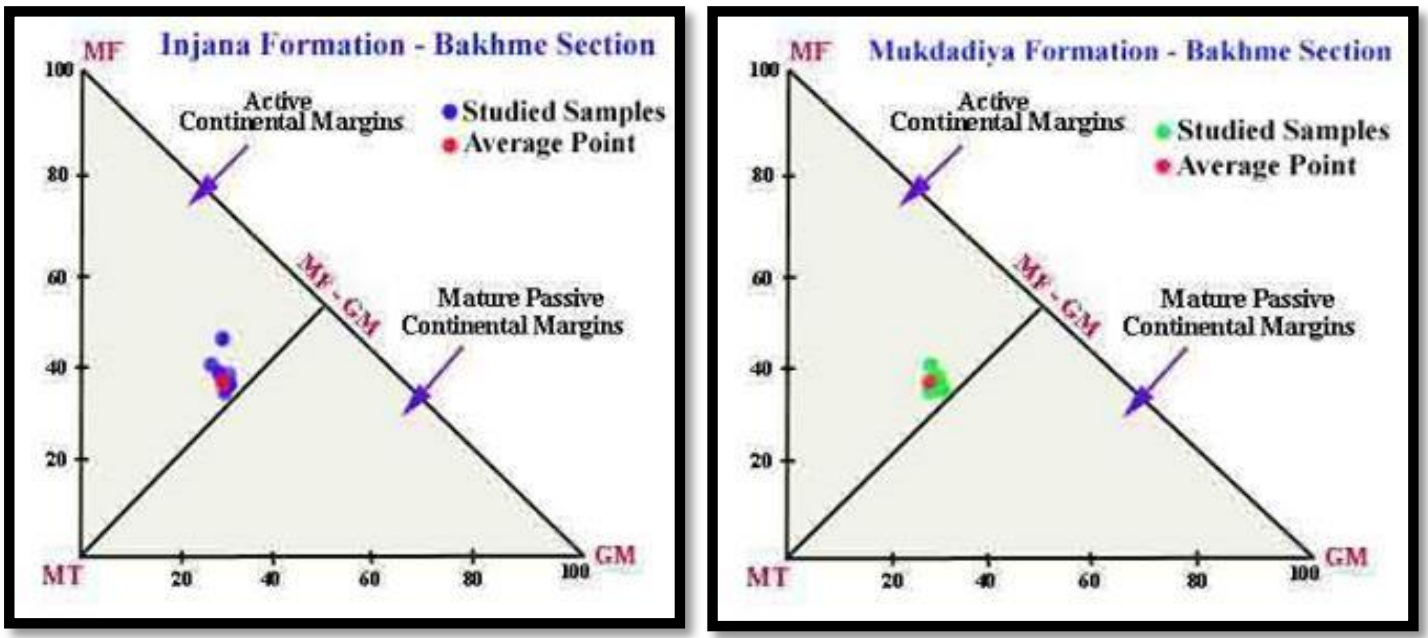

Figure 4- Interrelationship of the MF-MT-GM suites of Injana and Mukdadiya sandstone, after [18]. 


\section{Provenance from heavy minerals}

The analysis of heavy minerals is carried out in order to determine the provenance and tectonic setting of the source area. The present study observed the presence of opaques originate, mainly from mafic igneous and metamorphic rock, as well as acidic igneous and reworked sedimentary rock. Pyroxene is commonly distributed in the basic igneous rocks [19]. Glaucophene is characteristic of metamorphic rocks such as schist and gneiss [20]. Hornblende is common in mafic igneous and metamorphic rocks [21]. Epidote, garnet, chlorite, amphibole (tremolite-actinolte and glaucophane), kyanite, staurolite and sillimanite indicate a metamorphic source [22]. Biotite is derived from acidic igneous and metamorphic rocks [23, 24]. Chromian spinel is a common accessory mineral of ultramafic igneous rocks [25]. The euhedral form of zircon indicates acid igneous rock, where zircon occurs in acid and intermediate igneous rocks [22]. The presence of rutile is characteristic of a provenance of metamorphosed of argillaceous sediments of a high grade schist as well as acidic igneous rock [17]. The presence of tourmaline indicates the granitic pegmatites and acidic igneous sources [17]. The presence of rounded to subrounded grains such as some opaques, zircon, and tourmaline indicates a reworked sedimentary source $[26,27]$. The results of heavy minerals analysis for the studied samples of Injana and Mukdadiya Formations indicate that the source rocks are essentially basic, ultra-basic and metamorphic rocks, in addition to reworked sedimentary and acidic igneous rocks.

\section{Conclusions}

The presence of different kinds of heavy minerals indicates various source rocks. The heavy minerals accumulation comprises a very high percentage of opaques relative to the other heavy minerals that are indicated to derive mainly from mafic igneous and metamorphic sources, as well as acidic igneous and reworked sediments sources. The existence of unstable heavy minerals indicates the closeness sources rock. The Heavy mineral assemblage and the continental margin activity of the sandstone Injana and Mukdadiya Formations indicate active continental margins. Application of the stability factor on the studied sandstone of Injana and Mukdadiya Formations showed that all samples are moderately stable. The results of heavy minerals analysis for the studied samples indicated that the source rocks are essentially, basic, ultra-basic and metamorphic rocks, in addition to reworked sedimentary and acidic igneous rocks. Both sandstones are derived from active continental margins. These source rocks may be represented by Taurus and Zagros Mountains.

\section{References}

1. Bellen, R. C., Dunnington, H. V., Wetzel, R. and Morton, D. M. 1959. Lexique stratigraphic international Asia, Fascicule, 10a, Iraq, Central National deal Researches Scientifique, Paris, 333p.

2. Buday, T. 1980. The Regional Geology of Iraq (Stratigraphy and Paleontology), Dar Al-Kutb Publishing House, Mosul, Iraq, 443p.

3. Basi, M. A. and Jassim, S.Z. 1974. Baked and fused Miocene sediments from Injana area. Himreen south. Iraq: Jour. Geol.

4. Al-Rawi, Y. T., Sayyab, A. S., Jassim, J. A., Tamar-Agha, M. Y., Al-Samarrai, K. I., Karim, S. A., Basi, M. A., Dhiab, S. H., Faris, F. M. and Anwar, F. 1992. New names for some of the Middle Miocene-Pliocene Formations of Iraq (Fatha, Injana, Mukdadiya and Bai-Hassan Formations). Iraqi, Geol. J. 1: 1-18.

5. Jassim SZ, Goff JC 2006. Geology of Iraq. Published by Dolin, Prague and Moravian Museum, Brno. 1-345

6. Al-Juboury, A. I. 1994. Petrology and provenance of the Upper Fars Formation, Northern Iraq, Acta. Geologica Universitatis Commenianae (Slovakia), 50: 45-53.

7. Salman, N. A. 2014. The Sedimentology of Injana Formation in Zawita, Amadiya and Zakho areas Northern Iraq. Unpubl. M.Sc. Thesis University of Baghdad, Coll. Of Sc. 93p.

8. Al-Salmani, N. Z. 2018. Provenance Analysis of Injana and Mukdadiya Formations (Miocene/Pliocene) in Duhok Governorate, Northern Iraq. Unpubl. M.Sc. Thesis University of Baghdad, Coll. Of Sc. 39p.

9. Jasim, H. K. 2009. Petrography and Sedimentology of Al-Mukdadiya Formation in Badra area Eastern Iraq. Unpubl. M.Sc. Thesis University of Baghdad, Coll. Of Sc. 153p. 
10. Al-Khalidi, R. M. 2014. Petrography and Geochemistry of Mukdadiya Formation in Zawita and Amadia areas Northern Iraq. Unpubl. M.Sc. Thesis University of Baghdad, Coll. Of Sc. 126p.

11. Fouad S. F. A. 2012. Tectonic Map of Iraq, Scale 1: 1000000 3rd edition, IRAQ GEOLOGICAL SURVEY. Baghdad, Iraq.

12. Sharland, P. R., Archer, R., Casey, D. M., Hall, S.H., Heward, A. P., Horbury, A. D. and Simmons, M. D. 2001. Arabian Plate Sequence Stratigraphy. GeoArabia Special Puplication 2, Gulf Petrolink, Bahrain, 371p.

13. Tucker, M. E. 1988. Techniques in Sedimentology. Black Well. Oxford. 394p.

14. Carver, R. E. 1971. Procedures in Sedimentary Petrology. John Wiley and Sons, New York, $653 p$.

15. Folk, R.L. 1974. Petrology of Sedimentary Rocks, Hemphill Publishing Comp., Texas, 182p.

16. Kasper-Zubillaga, J. J., Dickinson, W. W., Carranza Edwards, A., and Hornelas-Orozeo, Y, 2008. Petrography of Quartz Grains in Beach and Dune Sand of Northland, North Island, New Zealand. N. Z. J. Geol. Geophys. 48: 649-660.

17. Pettijohn, F.J., Potter, P.E. and Siever, R. 1987. (Edit) Sand and sandstones. Springer- Verlag. New York, 553p.

18. Nechoev, V. B. and Isophording, W. C. 1993. Heavy Mineral Assemblages of Continental Margins as Indicators of Plate-Tectonic Environments. Jour. Sed. Petrol. 63(6): 1110-1117.

19. Tucker, M. E. 1991. Sedimentary Petrology, an Introduction to the Origin of Sedimentary Rocks, $2^{\text {nd }}$. Back Well Sci. Lid, $560 \mathrm{p}$

20. Boggs, S. Jr. 1995. Principles of sedimentology and stratigraphy, Prentice Hall, New Jersey. $774 \mathrm{p}$.

21. Pettijohn, F. Potter, P.E. and Siever, R. 1973. Sand and Sandstones. Springer- Verlag, New York, $618 \mathrm{p}$.

22. Milner, H. B. 1962. Sedimentary petrography, 2nd Ed, (edits): Vol.1, Methods in sedimentary petrography; Vol. 2, Principles and applications: New York, Macmillan Company, Vol.1, 643p, Vol.2, 715p.

23. Dana, E. S. 1982. Dana's system of mineralogy, 6th edition, S. J. Wiley, New York, pp. (419421).

24. Hibbard, M. J. 2002. Mineralogy. A geologist point of view. McCraw-Hill-Higher education, New York. 562p.

25. Mange, M. A. and Maurer H. F. 1992. Heavy minerals in colour. 1ed. Publ. Chapman and Hell. Hong kong. 154p.

26. Keer, P. F. 1959. Optical mineralogy. McGraw-Hill Book Company, New York, 442p.

27. Greensmith, J. T. 1988. Petrology of the sedimentary rocks. Allen and Unwin, London. 